\title{
P258: Incidence and risk factors of bacteremia associated with care intensive care environment: study in Chu Sahloul (Sousse Tunisia)
}

\author{
D Chebil', M Ben Rejeb, H Latiri, N Jaidane, S Khefacha, M Miladi, K Ben Alaya, L Dhidah \\ From 2nd International Conference on Prevention and Infection Control (ICPIC 2013) \\ Geneva, Switzerland. 25-28 June 2013
}

\section{Introduction}

In the context of the fight against healthcare associated infections (IAS) in intensive care, the CLIN in collaboration with hospital hygiene service, have established a system of epidemiological surveillance to investigate the risk factors of IAS including bacteremia (BAS).

\section{Methods}

This is a longitudinal study conducted in the University Hospital Intensive Care services Sahloul during 2010 2011. We included all patients hospitalized for more than 48 hours. This study is based on the French national protocol GRAPE-REA 2004. Analysis of data was performed by the software SPSS 19.0.

\section{Results}

We included 301 patients. Among them, 21 had BAS with an estimated incidence of $7 \%$. The univariate analysis identified as risk factors: age, SAPS II, and duration of intubation, tracheotomy, urinary catheterization and the duration, central venous catheterization and its duration.

In addition, multivariate analysis highlighted intubation and tracheostomy as independent risk factors.

\section{Conclusion}

Invasive devices play a major role in the development of BAS. They urge us to review the practices in intensive care units related to indications of these devices.

\section{Competing interests}

None declared.

Microbiology Laboratory, Hospital of Sahloul, Sousse, Tunisia
Published: 20 June 2013

doi:10.1186/2047-2994-2-S1-P258

Cite this article as: Chebil et al:: P258: Incidence and risk factors of bacteremia associated with care intensive care environment: study in Chu Sahloul (Sousse Tunisia). Antimicrobial Resistance and Infection Control 2013 2(Suppl 1):P258.
Submit your next manuscript to BioMed Central and take full advantage of:

- Convenient online submission

- Thorough peer review

- No space constraints or color figure charges

- Immediate publication on acceptance

- Inclusion in PubMed, CAS, Scopus and Google Scholar

- Research which is freely available for redistribution

\section{() Biomed Central}

(c) 2013 Chebil et al; licensee BioMed Central Ltd. This is an Open Access article distributed under the terms of the Creative Commons Attribution License (http://creativecommons.org/licenses/by/2.0), which permits unrestricted use, distribution, and reproduction in any medium, provided the original work is properly cited. 